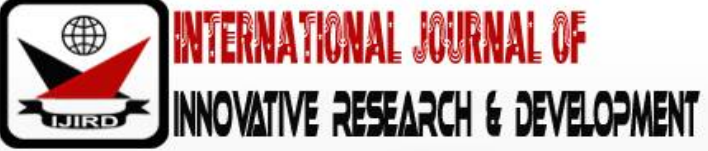

ISSN 2278 - 0211 (Online)

\section{Hard Skills Development and Self-Sufficiency for Functional Entrepreneurial Education in Akwa Ibom State, Nigeria}

\author{
Dr. Nsikak-Abasi Udofia \\ Associate Professor, Department of Educational Foundations, Guidance and Counselling. \\ University of Uyo, Nigeria \\ Idongesit Uwem Ikpe \\ Postgraduate Student, Department of Educational Foundations, Guidance and Counselling. \\ Institution name: University of Uyo, Nigeria
}

\begin{abstract}
:
The study was carried out to determine the extent of relationship that exists between hard skills development and selfsufficiency for functional entrepreneurial development in AkwaIbom State. The descriptive survey design was adopted for this study. The population of the study consisted of all the students in Senior Secondary Two (SS II) in the five selected public secondary schools in Uyo Local Government Area of AkwaIbom State. A sample of 200 students was selected for the study using simple random sampling technique. The instrument used in data collection was "Questionnaire on Hard Skills Development and Self Sufficiency (QHSDSS)." The instrument was used to obtain information with regards to both the dependent and independent variables. The reliability of the instrument using Cronbach alpha was .86. Four null hypotheses based on the four variables, were formulated and tested at 0.05 significance level using the Pearson Product Moment Correlation analysis. The results indicated that there is a significant relationship between hard skills development and self-sufficiency. Based on the results of the data analysis, a conclusion was drawn that hard skills development significantly relate to self-sufficiency among students of Uyo Local Government Area of AkwaIbom State. On the basis of the findings of the study and the conclusions reached, it was recommended among others, that ICT skills which are currently in high demand be included in the curriculum which would lead to students becoming financially self-sufficient. This will make for a functional entrepreneurial education and a panacea for unemployment problems in AkwaIbom State.
\end{abstract}

Keywords: Self-suffeciency, self-development, entrepreneurship education, sustainable development, hard skills

\section{Introduction}

In Nigeria, the available public and civil service employment vacancies are less than the graduates it produces from schools and higher institutions yearly. This situation has led to increase in anti-social vices such as armed robbery, thuggery, kidnapping, fraud etc. Iwele, Nyorere and Nkechi (2015) posited that most of those who engaged in thuggery and other social vices do that out of frustration and disappointment resulting from being unemployed. Experts suggests that these can be reversed through entrepreneurship education. This has led the government of Nigeria to place emphasis on entrepreneurial education in its higher institutions of learning, seemingly as a means to attaining self-sufficiency and sustainable self-development. According to Rajeev (2013), there is a growing academic interest in entrepreneurship which has triggered lots of researches, most of which are on the reasons for the increase in entrepreneurship. Richen and Salagnik cited by Ifeakor and Enenuo (2009) regarded entrepreneurial skills as relevant skills and competences which will enable an individual seek and run an establishment successfully. Such an individual should be able to maximize the transformation of available resources into wealth.

Entrepreneurship education is a form of special training organized for students with the aim of providing them the opportunity to acquire skills, ideas, capabilities and managerial abilities for self-employment. Agomuo (2015) opined that entrepreneurship education has become the vogue in contemporary economic development and that any wellmeaning and serious architecture for economic growth and development must focus on entrepreneurship education. Entrepreneurship education should not only focus on training students on skill acquisition but should also impact on their mental re-orientation. This means that students have to be trained to have a positive mindset towards self-employment especially the idea of not feeling frustrated about starting small in whatever form of business they decide to venture into. This is one of the challenges facing the society as most youths have the mentality of getting office work which includes working in a properly furnished office and earning a fat sum of money as salary immediately after graduation. They find 
starting small business ventures demeaning. Ezebgbe, Eskay and Anyanuou (2012) in Akpan, Usip and Uko (2015) posited that both government and the society have poor attitude towards entrepreneurship and vocational education training. There has been a misconception that education for white collar job is superior to education that leads to acquisition of entrepreneurial skills or workshop-based skills. However, entrepreneurial skills in Information and Communication Technology are more acceptable among the youths. Business centres and cyber centres are created even by the way side under temporary accommodation.

Information and Communication Technology (ICT) has become a leading engine of economic growth and development. This is due to its widespread impact on business, government and the society. It is defined as any material that creates stores and has the ability to exchange the information (Onyejemezi, 2001). In recent times, hard skills relating to computer knowledge have become lucrative with the advancement in ICT. ICT incorporates most of the hard skills which are greatly required as a prerequisite for employment by employers of labour, and which is also a good source of self-employment for most individuals. Hard skills are specific, teachable skills that can be defined and measured and as such requires competent professionals in the various skills to teach in entrepreneurial education. These skills include system management, typing, management of programmes, computation, graphic designing, digital marketing etc.

The Nigeria educational institutions keep turning out graduates yearly, yet unemployment and lack of jobopportunities continues to increase in all sectors of the economy. It is alarming to find graduates unable to start a venture even after learning one entrepreneurial skill or the other. Most often the excuse given is lack of fund to begin a business venture. This is actually true as every business requires some amount of capital to start-up. However, computer related hard skills are cheap to operate since the major equipment needed is a computer, and a working space which could be the comfort of one's room.

\section{Research Questions}

- To what extent does developing computer programming skills relate with self-sufficiency for functional entrepreneurship?

- To what extent does developing computational skills relate with self-sufficiency for functional entrepreneurship?

- To what extent does developing digital network marketing skills relate with self-sufficiency for functional entrepreneurship?

- To what extent does developing typesetting relate with self-sufficiency for functional entrepreneurship?

\section{Hypotheses}

- Developing computer programming skills does not significantly relate with self-sufficiency for functional entrepreneurship.

- Developing computational skills does not significantly relate with self-sufficiency for functional entrepreneurship.

- Developing digital network marketing skills does not significantly relate with self-sufficiency for functional entrepreneurship.

- Developing typesetting skills does not significantly relate with self-sufficiency for functional entrepreneurship.

\section{Research Methods}

The method of the research is presented under the following subheading. Area of the study, Sample/ Sampling technique, Population of the study, Research instrumentation, Validation of the instrument, Reliability of the instrument, Administration of instrument and method of Data Analysis

The research adopted a descriptive survey design in which the questionnaire was used for data collection. The descriptive design is appropriate when trying to compare, contrast and find out the relationship that exist between variables involved in a study (Udoh and Joseph, 2005). The descriptive survey design made it easy for reference on the population to be drawn using a random sample.

The area of the study was Uyo Local Government Area of Akwalbom State. The town became the capital of AkwaIbom State on September 23, 1987 following the creation of AkwaIbom State from erstwhile Cross River State. The population of Uyo, according to the 2006 Nigerian Census comprised of Uyo which was 427,873sq miles while the urban area, including Uruan is 554,906sq mile. Uyo is located between the latitude of 5020N7055ㄹ and longitude of 7, 9333 (755'59.998'E), with altitude of 191 meters (http:// / www.Ibomelibrary.org, retrieved 2015-11-22).

The inhabitants of Uyo engage in the Civil Service. A significant number of others also engage in trading, tailoring, commercial driving of tricycle (keke), and other economic ventures such as; welding and fabrication, block molding vehicle repairs among others (encyclopedia.com.26Nov.2015http:// / www.enclopedia.com). Uyo was specially adopted for this study by the researcher because of deliberate observation of students' attitude to schooling these days in the cities due to lack of professional guidance counselors in most of the public secondary schools in the area. The town just like any other town in Nigeria suffers from a very high rate of unemployment.

The population of this study was made up of all the students in Senior Secondary Two (SSII) in five selected Public Secondary Schools in Uyo Local Government Area of AkwaIbom State. The population stood at 1410 for the 2014/ 2015 school session. The study was made up of 200 students selected using simple random sampling technique from the population of 1410 students.

The researcher developed an instrument titled "Questionnaire on Hard Skills Development and Self Sufficiency (QHSDSS). This instrument was made up of two sections, section A which is made up of respondent's personal data, while section B, consisted of items. The instrument was a four-point scale. The scale carried the following scores: Strongly Agree (SA) - 4 point, Agree (A) - 3 point, Disagree (D) - 2 point, and Strongly Disagree - 1 point respectively. The items in the 
questionnaire were vetted and reviewed by three experts in vocational education and Test and Measurement. They made recommendations on the suitability and adequate of the item. These were used to update the questionnaire. To find out the reliability of the instrument, copies of Hard Skills Development and Self Sufficiency (HSDSS) questionnaire were administered to 30 students who were not part of the sample size selected for this study but were found to be equivalent to the research groups under investigation. The reliability was 0.86 . The researchers then trained research assistants who visited the schools selected for the study, distributed the questionnaire and retrieved same day from the respondents and this accounted for a 100 percent return rate recorded. The data were analyzed using Pearson Product Moment Correlation. Each hypothesis was tested at.05 level of significance.

\section{Results}

\begin{tabular}{|c|c|c|c|c|c|}
\hline Variables & $\begin{array}{l}\sum \mathbf{x} \\
\sum \mathbf{y}\end{array}$ & $\begin{array}{l}\sum x^{2} \\
\sum y^{2}\end{array}$ & $\sum x y$ & r-cal & r.crit \\
\hline $\begin{array}{c}\text { Developing computer } \\
\text { programming }\end{array}$ & 7265 & \multirow{2}{*}{$\begin{array}{r}30266 \\
38455\end{array}$} & \multirow[t]{2}{*}{524518} & \multirow[t]{2}{*}{$0.79 *$} & \multirow[t]{2}{*}{0.113} \\
\hline Self-sufficiency & & & & & \\
\hline
\end{tabular}

Table 1: Pearson Product Moment Correlation of Computer Programming Skills and Self-Sufficiency for Functional Entrepreneurship $* \mathrm{P}<05 ; \mathrm{df}=198, \mathrm{n}=200$

The data shown in Table 1 shows that the calculated r-value of 0.79 is significantly higher than the critical r-value of .113 at .05 level of significance and 198 degree of freedom. The null hypothesis which stated that Developing Computer Programming Skills does not significantly relate with self-sufficiency for functional entrepreneurship was rejected. This implies that developing computer Programming kills significantly relate with self-sufficiency for functional entrepreneurship.

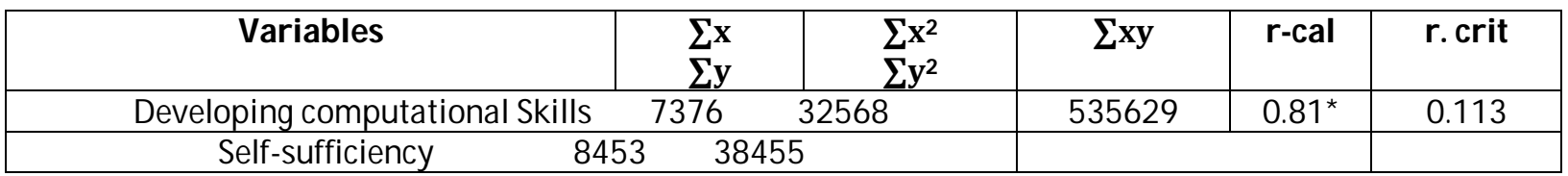

Table 2: Pearson Product Correlation Analysis on Developing Computational Skills

Does Not Significantly Relate with Self-Sufficiency for Functional Entrepreneurship $* \mathrm{P}<05 ; \mathrm{Df}=198 ; \mathrm{N}=200$

The result of data analysis shown in Table 2 revealed that the calculated r-value of 0.81 was significantly higher than the critical r-value of 0.113 of .05 level of significance and 198 degree of freedom. The null hypotheses Developing Computational Skills does not significantly relate with self-sufficiency for functional entrepreneurship was therefore rejected. This implies that developing computational skills significantly relate with self-sufficiency for functional entrepreneurship.

\begin{tabular}{|c|c|c|c|c|c|}
\hline Variables & $\sum \mathbf{x}$ & $\sum x^{2}$ & $\sum x y$ & r-cal & r. crit \\
\hline $\begin{array}{l}\text { Developing digital network } \\
\text { marketing skills }\end{array}$ & 7376 & 32568 & 535234 & $0.86^{*}$ & 0.113 \\
\hline
\end{tabular}

Table 3: Pearson Product Moment Correlational Analysis on Developing Digital

Network Marketing Skills and Self-Sufficiency for Functional Entrepreneurship $* \mathrm{P}<05 ; \mathrm{DF}=198 ; \mathrm{N}=200$

The result of data analysis in Table 3 reveals that the calculated r-value of 0.86 is significantly higher than the critical r-value of 0.113 at 0.5 level of significance and 198 degree of freedom. The null hypothesis developing digital network marketing Skills does not significantly relate with self -sufficiency for functional entrepreneurship was rejected. This implies that there is a strong relationship between developing digital network Marketing Skills and self-sufficiency for functional entrepreneurship.

\begin{tabular}{|c|c|c|c|c|c|}
\hline Variables & $\mathbf{\sum x}$ & $\sum \mathbf{x}^{\mathbf{2}}$ & $\mathbf{2 x y}$ & r-cal & r. crit \\
\hline Typesetting skills & $\mathbf{\sum y}$ & $\mathbf{\sum \mathbf { y } ^ { 2 }}$ & & & \\
\hline Self Sufficiency & 8453 & 30266 & 498762 & $0.75^{*}$ & 0.113 \\
\hline
\end{tabular}

Table 4: Pearson Product Moment Correlation Analysis on Developing Type

Setting and Self Sufficiency for Functional Entrepreneurship

$$
* \mathrm{P}<05, \mathrm{DF}=198 ; \mathrm{n}=200
$$


The result of data analysis shows in Table 4 revealed that the calculated r-value of.75 at .05 level of significance and 198 degree of freedom was higher than the critical r-value of 0.113. Developing typesetting skills does not significantly with self -sufficiency relate for functional entrepreneurship was rejected. Therefore, developing typesetting skills significantly relate with self- sufficiency for functional entrepreneurship.

\section{Discussion of Findings}

Computational programming skills, computational skills, developing network marketing skills and typesetting skills are the hard skills studied in this work. When emphasis is laid on entrepreneurship, the possession of hard skills becomes very necessary. As this work showed significant relationship, it is quite a welcome development; it means if hard skills are developed it will be good for the people. This is in line with the opinion of Agomuo (2015) that entrepreneurship education is what is needed in the present generation. As observed by Ezebge, Eskay and Anyanuou (2002), it was considered that the main problem of entrepreneurship acquisition was the inability of the youth to develop the mentality needed for entrepreneurship start up and sustainability.

Hard skills do not fall into this line, since it follows the (ICT) and computer demands of the time. In other words, the youth will love to acquire hard skills and will love to exhibit it. This is because hard skills are in vogue and is modern which is different from the other traditional entrepreneurial skills which the youth regard as craft and artesian and therefore require a new mental orientation to acquire and exhibit them. This is also a good development for the government and society since this will involve not only skill acquisition but effective citizenship. It will decrease unemployment and will encourage entrepreneurship, since hard skill is exotic and in vogue, it will encourage functional entrepreneurship.

This study has provided enough reason to encourage hard skills acquisition as it shows that hard skills development significantly relates with self-sufficiency needed for functional entrepreneurial education.

\section{Conclusion}

In the light of the findings of this study, conclusion was drawn that hard skills development significantly relate to self-sufficiency among students of Uyo Local Government Area of AkwaIbom State.

\section{Recommendations}

- Curriculum planners should review the curriculum for more practical oriented learning thereby ensuring that students actually learn and can practice what they learnt.

- ICT skills which are currently in high demand for example the ones identified in this research should be included in the curriculum to enable students be financially self-sufficient.

- All tiers of government should support ICT related hard skills development by providing budgetary allocation to schools.

- Stakeholders in education and private individuals should procure ICT facilities for use in schools to enable students to be exposed to the practical aspect of the course.

- Counselors, teachers, and parents should help to change the mindset of youths regarding entrepreneurship.

\section{References}

i. Agomuo, E. E. (2015). Entrepreneurship Education in Nigeria: Issue and Challenges. Journal of Education, 8(1): 1-8.

ii. Akpan, G., Usip, M. E. \& Uko, E. C. (2015). Entrepreneurship Education: A Panacea for Youth Unemployment in Nigeria. Journal of Education, 8(1): 79-87.

iii. Amazu, N. A., Ekott, I. B. \& Amajuoyi, I. J. (2015). Students' and Teachers' variables as Determinants of Secondary School Students' Attitudes Toward Entrepreneurial Education, Journal of Education, 8(1): 299-308.

iv. Ifeakor, A. C.\&, Enemuo, J. O. (2009). Evaluating the Impact of Teacher Factor for the Development of Entrepreneurship Skills through Science, Technology and Mathematics Education (STME)..$^{\text {th }}$ Annual Conference of STAN Abuja HEBN Publisher.

v. Iwele, M. U. Nyorere, O. I. \& Nkechi, U. L. (2015). Restrategizing Entrepreneurship Education for curbing social vices in Nigeria. Journal of Education, 8(1): 177-185.

vi. Onyejemezi, D. A (2001). New Information and Communication Technology and their uses in Education. Faculty of Education, Imo State University (Monograph).

vii. $\quad$ Rajeev, R. (2013). Entrepreneurship, New Delhi, Oxford University Press.

viii. Udo, A. O. \& Joseph, E. U. (2005). Foundations of Educational Research.IkotEkpene: Joe Graph Publications. 